University of Michigan Law School

University of Michigan Law School Scholarship Repository

Law \& Economics Working Papers

7-1-2014

\title{
Concentrated Ownership and Corporate Control: Wallenberg Sphere and Samsung Group
}

\author{
Hwa-Jin Kim \\ Seoul National University; University of Michigan Law School, Ibfk@umich.edu
}

Follow this and additional works at: https://repository.law.umich.edu/law_econ_current

Part of the Business Organizations Law Commons

\section{Working Paper Citation}

Kim, Hwa-Jin, "Concentrated Ownership and Corporate Control: Wallenberg Sphere and Samsung Group" (2014). Law \& Economics Working Papers. 105.

https://repository.law.umich.edu/law_econ_current/105

This Article is brought to you for free and open access by University of Michigan Law School Scholarship Repository. It has been accepted for inclusion in Law \& Economics Working Papers by an authorized administrator of University of Michigan Law School Scholarship Repository. For more information, please contact mlaw.repository@umich.edu. 


\title{
Concentrated Ownership and Corporate Control: Wallenberg Sphere and Samsung Group
}

\author{
Hwa-Jin Kim*
}

\begin{abstract}
Samsung Group's success cannot be attributed to its corporate governance structure, at least thus far. The corporate governance of Samsung has been rather controversial. As the group faces the succession issue the corporate governance has become as crucial as their new products and services. Samsung has discovered a role model on the other side of the planet, Wallenberg Sphere in Sweden. Much effort has been made to learn about Wallenberg's arrangements and key to its success. However, a fundamental difference between the institutions in Sweden and Korea has made the corporate structures of the two groups radically different. Wallenberg uses the dualclass commons whereas Samsung relies upon the circular shareholdings through affiliated firms. This Essay explains and analyzes the two different institutions and corporate structures, and argues that the introduction of the dual-class commons in Korea would make the corporate governance of Samsung more transparent and efficient, if and only if accompanied by Samsung's commitment to socially responsible corporate citizenship. This Essay also explains and analyzes the recent developments in corporate governance of non-banking financial institutions in Korea and looks into the issue from the perspective of Samsung's structure in comparison with Wallenberg's structure.
\end{abstract}

\section{INTRODUCTION}

The Wallenberg Sphere of Sweden and Samsung Group of Korea share many things in common. Both are the flagship business conglomerates in their respective countries, significantly contributing to each nation's GDP. ${ }^{1}$ Both of them exercise substantial influence on the politics and society in their countries

* Professor of Law at Seoul National University, and William W. Cook Global Law Professor at the University of Michigan Law School.

${ }^{1}$ Samsung Group’s some 60 companies, including Samsung Electronics and Samsung Life Insurance, accounted for 13\% of Korea's GDP in 2011. See Mighty Samsung Weighs Heavy on S Korea, Financial Times, Nov. 14, 2012. The Wallenbergs owned some $40 \%$ of the value of the listed companies in Sweden by the late 1990s. See The Wallenbergs: Sweden's enduring business dynasty, The Economist, Oct. 12, 2006. 
due to the sheer volume of their production capabilities and number of employees, suppliers and customers.

From the perspective of corporate governance, they are controlled by the members of a family through concentrated ownership and other legal and practical arrangements. $^{2}$ For that reason, along with the economic power concentration concern, Wallenberg used to be, and Samsung has been highly controversial for many years. And perhaps for that reason again, the two groups of companies and their people in charge remain close to each other, ${ }^{3}$ having developed some sort of moral alliance and personal friendships. Given that Korea and Sweden historically were not closely related to each other, it is remarkable that Wallenberg's name has become quite recognizable in the Korean industry circle, and Samsung is responsible for it.

This Essay will explain and briefly analyze the corporate governance issues in the two groups from the perspective of comparative corporate law, practice, and finance. As a matter of fact, it is not a secret that Samsung regards Wallenberg as its model in corporate governance, control, and citizenship. In particular, Samsung is interested in learning the way Wallenberg managed the corporate social responsibility issue and family control succession problem. One of the keys to understanding Wallenberg's "secret of success" lies in Sweden's corporate governance institutions which currently are not available to Samsung as a Korean corporate group. This Essay will focus on those differences and propose some institutional and practical changes to Samsung as well as the Korean government.

\section{THE WALLENBERG MODEL ${ }^{4}$}

\section{A. Corporate Structure}

${ }^{2}$ Concentrated ownership has been the hallmark of Asian and European firms. See Randall K. Morck ed., Concentrated Corporate Ownership (2000). But, current scholarship shows us that even in the United States the ownership of large firms is now highly concentrated, not with families but with institutional investors. See Ronald J. Gilson \& Jeffrey N. Gordon, The Agency Costs of Agency Capitalism: Activist Investors and the Revaluation of Governance Rights, 113 Columbia Law Review 863 (2013); Clifford G. Holderness, The Myth of Diffuse Ownership in the United States, 22 Review of Financial Studies 1377 (2007). 18, 2012.

3 See Powerful Swedish Family Arrives in Korea for Conference, The Dong-A Ilbo, March

${ }^{4}$ For Wallenberg and Swedish economy in general, see Lennart Schön, An Economic History of Modern Sweden (2012). 
The Swedish model of corporate governance gained much attention ever since the comparative corporate governance scholarship was born in the United States. ${ }^{5}$ Ronald Gilson is well known to be a big fan of the Swedish model. Gilson designated the Swedish model as an "efficient controlling shareholder system" 6 , based obviously on the conventional wisdom that the controlling (minority) shareholder system ${ }^{7}$ was not efficient.

The hallmark of the Wallenberg corporate structure is its family control over the entire group of companies, including such giants as Ericsson, Scania and $\mathrm{ABB}$, through the dual-class commons owned by Investor, the main company. Investor, in turn, is owned by the Wallenberg Foundations at $22 \%$ in equity and $46 \%$ in votes. Gilson even calls the dual-class commons structure as the "Swedish capital structure." In the Swedish capital structure "the founders retained stock with many times the voting power of the class of common stock sold to the public." 8 The Wallenberg family has maintained control over the group through an arrangement that creates huge discrepancy between their cash flow right and control right. Such a discrepancy typically is characterized as a sign of bad corporate governance by most scholarly opinions. ${ }^{9}$ However, the Wallenberg structure is an exception and accepted by the Swedish society largely due to Wallenberg's social commitments and lack of self-dealing and family members' entrenchment. The Wallenberg family controls and runs the businesses, but it does not "own" the franchise. No private benefit of control is known to be enjoyed by the family.

\section{B. Corporate Citizenship}

Much has been written about Raoul Wallenberg, the Swedish version of Oskar Schindler, who rescued tens of thousands Jews in Nazi-occupied Hungary

${ }^{5}$ See, e.g., Ronald J. Gilson \& Reinier Kraakman, Investment Companies as Guardian Shareholders: The Place of the MSIC in the Corporate Governance Debate, 45 Stanford Law Review 985 (1993). See also Peter Högfeldt, The History and Politics of Corporate Ownership in Sweden, in: Randall K. Morck ed., A History of Corporate Governance Around the World: Family Business Groups to Professional Managers 517 (2005).

6 See Ronald J. Gilson, Controlling Shareholders and Corporate Governance: Complicating the Comparative Taxonomy, 119 Harvard Law Review 1641 (2006).

${ }^{7}$ For CMS (Controlling Minority Structure), see Lucian A. Bebchuk et al., Stock Pyramids, Cross-Ownership, and Dual Class Equity, in Concentrated Corporate Ownership, supra note _ , at 295.

${ }^{8}$ See Gilson, supra note 6 at 1660.

${ }^{9}$ See, e.g., Stijn Claessens et al., The Separation of Ownership and Control in East Asian Corporations, 58 Journal of Financial Economics 81 (2000). 
during the later stages of the Second World War. ${ }^{10}$ The story fits very well with the Wallenberg's image of a conglomerate that has consistently tried to resonate with the Swedish society as a socially responsible corporate citizen. The Wallenberg Foundations also extensively support scientific research, higher education and the arts in Sweden.

The Wallenberg concentrates on such major businesses as Aerospace, Machinery and Telecommunications, leaving other areas of business to small enterprises. ${ }^{11}$ It also recognizes the labor union as partner, not party on the other side of the table representing the conflicting interest. This goes back to the triparty Saltsjöbaden Agreement that was signed by Swedish Trade Union Confederation (Landsorganisationen: LO) and Swedish Employers' Confederation (Svenska Arbetsgivareföreningen: SAF) on December 20, 1938 under the auspices of the government. Instead of nationalizing business groups' assets, the Swedish government and labor unions recognized the business groups' vested interests. Through the arrangement, they could keep the big businesses in Swedish territory, and gain their support for further social reform. Employers, in return, did agree to take higher corporate tax burden. This industrial relations regime did survive the far-reaching labor legislation around 1970, and remained effective until superseded by the Industrial Agreement of 1997, the new labor market regime in Sweden. ${ }^{12}$

\section{The SAMsung Issue In KoreA}

Corporate governance in Korea has "again” become a hot political and social issue. The Korean economy has long been dominated by Chaebols, ${ }^{13}$ large corporate conglomerates, including Samsung Group, throughout its past.

10 See, e.g., Kati Marton, Wallenberg: The Incredible True Story of the Man Who Saved the Jews of Budapest (2011); Alex Kershaw, The Envoy: The Epic Rescue of the Last Jews of Europe in the Desperate Closing Months of World War II (2010).

11 In Korea, big business groups expanded into small areas such as bakeries, restaurants and grocery stores. The problem is that those businesses are regularly run by children or relatives of controlling-shareholder managers of the business groups. This created outrage in the public opinion and led to the establishment of the National Commission for Corporate Partnership in 2010 under the Law for Promotion of Coexistence and Partnership between Big and Small and Medium Size Enterprises.

12 See Nils Elvander, Two Labour Market Regimes in Sweden: A Comparison Between the Saltsjöbaden Agreement of 1938 and the Industrial Agreement of 1997, 10 Industrielle Beziehungen 146 (2003).

${ }^{13}$ See Jeong Seo, Who Will Control Frankenstein? The Korean Chaebol's Corporate Governance, 14 Cardozo Journal of International \& Comparative Law 21 (2006); Myung Hun Kang, The Korean Business Conglomerate: Chaebol Then and Now (1996). 
Although corporate governance of Korean firms in general has significantly improved over time, the concentration of economic and even political powers on Chaebols have become more intense. ${ }^{14}$ Samsung stands in the middle of controversy. Although Samsung Group is a private business entity comprised of public and private companies, the public, the media and politicians closely follow its governance because it has heavy impacts on the markets and the nation's economy. ${ }^{15}$ Ever since the 2008 global financial crisis, antagonism amongst general population against Chaebols in general ${ }^{16}$ and Samsung in particular has grown significantly, while some corporate scandals and political campaigns did contribute to the trend.

\section{A. Succession Problem}

The controlling shareholder-managers of many Chaebols face the succession problem, with some of them committing questionable acts in the succession process causing big scandals and ending up standing before law enforcement agencies and courts. ${ }^{17}$

The best way to understand Samsung's issues is probably looking into its succession problem. It all starts with Cheil Industries (formerly Samsung Everland), a theme park housing lots of zoo animals like lions and tigers. Everland practically functions as the holding company of the Samsung Group. It controls Samsung Life Insurance, and in turn, the insurance giant controls Samsung Electronics, the flagship of the group. According to the Financial Times, as of December 2013 Samsung Electronics was the world's thirteenth largest company right after Johnson \& Johnson and followed by China Mobile.

Until recently, Cheil remained as a private firm owned largely by members of the Lee family. ${ }^{18}$ Cheil is the Samsung version of Wallenberg's

14 See Corporate Kingpins Living on Borrowed Time, Korea JoongAng Daily, Dec. 7, 2012 (reporting that a total of 30 largest conglomerates accounted for 95\% of GDP in 2011).

${ }^{15}$ Cf. Hillary A. Sale, The New "Public" Corporation, 74 Law and Contemporary Problems 137 (2011) (discussing increased “publicness” and the role of government in corporate governance of large public companies).

16 See, e.g., Simon Munday, South Korean Companies: Needed on the Home Front, Financial Times, Nov. 18, 2003.

17 See Hwa-Jin Kim, Seung-Hwan Lee \& Stephen Woodcock, Favoritism and Corporate Law: The Confused Corporate Opportunity Doctrine in the Hyundai Motor Case, 3 Michigan Journal of Private Equity \& Venture Capital Law 41 (2013).

18 The average ownership of the controlling shareholders of non-public member firms of Samsung Group was $78.43 \%$, whereas their cash-flow rights were as low as $19.43 \%$. For public member firms the number was $13.52 \%$ and $1.14 \%$, respectively. See James Jinho Chang \& Hyun- 
Investor. So, if control over Cheil gets passed on, the control over the whole group passes on. The question is to whom. Samsung's Chairman Lee has three children, a son and two daughters. They hold controlling shares in Cheil and some shares in other affiliate companies of the group. In 1996, an important decision was made. Where Cheil (Everland) offered a substantial amount of convertible bonds to the shareholders with preemptive rights. Almost all of the shareholders turned down the offer. Everland then "found" willing buyers from outside, Lee's children. The son got the lion's share and became the new largest shareholder in Everland. It seemed as if control over the group had been smoothly passed on to the son. However, the story had a surprising twist.

Five years after the transaction, 43 law professors brought criminal charges against the Everland managers. They thought that the price of convertible bonds was too low, resulting in a very cheap transfer of corporate control to the son to the detriment of the company's financials. After years of a lengthy and painful courtroom debacle, the Korean Supreme Court ultimately decided, by a five to four judgment, that the defendants were not guilty. ${ }^{19}$ The Supreme Court's judgment made the son's control over Everland legitimate, but the control and succession issue has not been solved yet.

The ultimate trouble is that the whole corporate structure of the Samsung Group has been built on the roundabout circular shareholding. Samsung Life controls Samsung Electronics, which controls Samsung Card, and Samsung Card in turn holds a sizable share in Samsung Life. ${ }^{20}$ It is now too big an entity for a family to maintain effective control without such an arrangement. It is almost like the Lee family controls the entire group through other people's money. On top of that, as Chairman Lee gets older, his two ambitious daughters may require their fair shares in the group. Also, they will have to pay inheritance taxes through selling the shares. To make the matter more difficult, two financial institutions, Samsung Life and Samsung Card, are involved in the structure, which invites political interference and, accordingly, makes the whole issue more difficult to solve.

Han Shin, Family Ownership and Performance in Korean Conglomerates, 15 Pacific-Basin Finance Journal 329 (2007).

${ }^{19}$ Supreme Court Judgment of May 29, 2009, 2005-No-2371: The entire judgment is available in Hwa-Jin Kim, Corporate Finance and Governance 462-482 (2 ${ }^{\text {nd }}$ ed., 2012) (Korean).

20 This structure comes up in the United States, too. See Speiser v. Baker, 525 A.2d 1001 (Del. Ch. 1987). In Germany, they call it "Ringförmige Mehrheitsbeteiligungen." See Friedrich Kübler, Gesellschaftsrecht 362 ( $5^{\text {th }}$ ed. 1998) (suggesting potential liability of directors who created the structure). 


\section{B. Social Responsibility}

From the perspective of stakeholder capitalism, ${ }^{21}$ Samsung's track record does not look that impressive. The most notable example is Samsung's decades long policy against labor unions. Also, its history has been tainted with such scandals as tax evasions and corrupt practices. ${ }^{22}$ Chairman Lee once stepped down from his office when the former general counsel of the group spoke out after the former public prosecutor met with some Catholic priests. A special prosecutor was appointed by the parliament, found some wrongdoings and indicted Lee. Samsung was forced to pledge for socially responsible management and committed a significant amount of funds for that purpose. This is the point where Samsung became eager to learn from Wallenberg's experiences.

The Code of Best Practice for Corporate Governance ${ }^{23}$ adopted by the Korean Committee on Corporate Governance in September 1999 declares that "[t]he corporation shall not be negligent in its social responsibilities, such as consumer protection and environmental protection."24 Actually, the notion that corporations are socially responsible was already widespread and well accepted under the authoritarian military governments from the 1960s through the 1980s. This notion is also related to the popular concept that socially responsible and "patriotic" business managers greatly contribute to the economic development of their "fatherland".

Socially responsible companies have been popular in Korea along the way. For instance, pharmaceutical companies act and present themselves almost like charitable institutions. Big companies build hospitals, museums and schools

21 See generally, Martin Gelter, The Dark Side of Shareholder Influence: Managerial Autonomy and Stakeholder Orientation in Comparative Corporate Governance, 50 Harvard International Law Journal 129 (2009); Lynn Stout, The Shareholder Value Myth (2012).

22 The family has also been involved in an inheritance dispute. See Court Sides with Samsung Electronics Chairman in Family Feud, Wall Street Journal, Feb. 1, 2013; Feud Among Samsung Descendants Heats Up, New York Times, Nov. 14, 2012.

${ }^{23}$ Committee on Corporate Governance, Code of Best Practice for Corporate Governance (September 1999).

24 Section IV-1.3. ("With the significant rise of corporation's influence on the economy and society, similarly increasing has been the recognition of general public's concern about corporation's social responsibilities. Also, consumers and regional societies have been increasing in importance as interested parties in the continuance of the corporation. In particular, if the corporation neglects its social responsibilities, such as protecting consumer rights or the environment using its vantage, it will, unlike the past, lead to a very adverse effect on its long-term development as well as to a decline in its image. Therefore, each corporation shall enable its managers to faithfully perform its social responsibilities through an appropriate governance system.”) 
and establish endowments. ${ }^{25}$ Samsung also runs one of the finest hospitals in Korea. Cheil, together with Samsung Life, has a guide dogs program with many Labrador Retrievers. Whenever a national disaster occurs, the media enthusiastically reports on contributions made by the companies with references to the amounts contributed, sometimes ranked by size. The websites of major corporations in Korea, including those of Samsung and LG, very proudly introduce how they value the concept of corporate social responsibility and that their performance has been in line with such a concept.

On the other hand, there were and are many controlling shareholdermanagers in Korea who voluntarily assume unlimited responsibility for their companies. They take the financial responsibility of their firms on themselves by issuing guarantees for the firms' debt, and by other methods, voluntarily giving up the benefit of the limited liability principle as they put their personal properties into the corporation when the firm is in trouble to save the firm and employees' jobs and even compensate for losses incurred by the firm's customers. This would be surprising if it were to happen in a Fortune 500 International public firm. ${ }^{26}$

However, most legal scholars in Korea are skeptical about bringing the concept of corporate social responsibility into a statute. ${ }^{27}$ Corporate social responsibility, however good it may be, may become a simple "guidance" that does not help judges. It is argued that it is not clear who is the legal beneficiary of the directors' obligation to act in a socially responsible way. Also, such a law may be abused under sensitive and unstable political circumstances. Management might use the concept to sacrifice shareholder interests. ${ }^{28}$ Korean corporate law as it stands today does not provide the non-shareholder stakeholders of a corporation with any kind of legal right as far as corporate governance is

25 Like Wallenbergs did, some of the endowments and foundations were used to place part of a controlling block of shares in friendly hands. Such a practice was also popular because it could mitigate the inheritance tax burden without diluting control. The Korean government took some measures to curb the practice in 1997 through a tax law reform.

${ }^{26}$ Also, Korean banks usually require the controlling-shareholder managers and other key officers to issue personal guarantees for a firm's debts. The Korean banking practice heavily relies upon secured lending. If the firm fails, the controlling-shareholder manager loses everything, unless he or she runs some kind of safety funds.

27 See, e.g., Chul Song Lee, Corporate Law 66 -67 (20 $0^{\text {th }}$ ed., 2012) (Korean).

${ }^{28}$ In Japan, the House of Representatives resolved twice (in 1973 and 1981) to require the government to codify the concept, but nothing happened. Id. at 66. 
concerned. Non-shareholder stakeholders can only protect their legitimate interests through contract, tax and labor law. ${ }^{29}$

Korea is currently also under the strong influence of the paradigm change that took place after the global financial crisis and 'Occupy Wall Street' campaign. In the presidential election of 2012, all candidates promised to do something about the current model of economy. The discussion of corporate social responsibility has regained the focus in the context of 'economic democracy.' As the biggest business entity in Korea, Samsung is under pressure and should come up with a new idea and policy that may satisfactorily answer the requirements newly made by Korean society.

\section{The Case for Dual-Class Commons}

The dual-class common stock structure, or the "Swedish capital structure" as Gilson puts it, is popular in Europe ${ }^{30}$ but it is also widely used in the United States $^{31}$ in the big public companies as well as venture capital-backed companies undergoing IPOs. ${ }^{32}$ The most well-known example of the concentrated ownership with the dual-class structure in the U.S. is Berkshire Hathaway, one of the most profitable and respected firms in the world. ${ }^{33}$ The difference between Berkshire, Wallenberg and Samsung is that Berkshire is under the control of individual

${ }^{29}$ See Section IV-1.2 of the Code: "The corporation shall make every effort to maintain and improve labor conditions by faithfully observing labor-related statutes such as the Labor Standard Act." See also Section IV-2.1 of the Code: "The form and level of management monitoring by creditors shall be determined through discussion among the related parties, according to the corporation's distinctive qualities.” The Korean Act on Worker Participation and Promotion of Cooperation is basically a labor law statute that enforces convening of labormanagement consultative meetings, during which employers are required to report and explain the business plans/strategies, matters concerning their implementation, quarterly production plans and performances, personnel plans, and the corporation's financial status. So, it cannot be compared with the German co-determination.

30 Report on the Proportionality Principle in the European Union (18 May 2007).

31 See Jeffrey N. Gordon, Ties That Bond: Dual Class Common Stock and the Problem of Shareholder Choice, 76 California Law Review 1 (1988).

32 See, e.g., Laura Field \& Jonathan Karpoff, Takeover Defenses of IPO Firms, 57 Journal of Finance 1857 (2002).

${ }^{33}$ By conventional standards, the corporate governance of Berkshire cannot be positively evaluated. The gap between cash flow right and control right is big. Its aging board does not look that independent, etc. Perhaps, the firm represents the extremely rare benevolent dictatorship model that makes all discussions trivial. 
managers led by Warren Buffett, ${ }^{34}$ not families. The enterprise has neither been inherited nor faces the bloodline succession problem.

The dual-class structure is regarded as an antitakeover arrangement, ${ }^{35}$ but that is not all that it does. The dual class share system is relatively more transparent compared to cross-shareholdings or pyramid type structures. ${ }^{36}$ If the dual-class stock system is abolished, the relevant companies will restructure the corporate governance through adopting cross-shareholding or creating a pyramid to protect its incumbent manager's vested interests. ${ }^{37}$

One of the reasons that the Korean Chaebols use complicated shareholding structures is a legal one. The KCC does not allow firms to issue dual-class common stocks. The one-share-one-vote rule in the $\mathrm{KCC}^{38}$ has been regarded as mandatory and, may not be opted out through charter provisions. Large Korean firms have been growing so rapidly that the controlling shareholder-managers could not keep up with the speed of their firms' growths. In order to avoid the dilution of their shareholding, they built the massive circular shareholding structures and inter-locking directorships. They control practically one business entity with very little direct investment. Ironically, the ban on dualclass commons has made the corporate structure of Korean conglomerates less transparent.

34 See Alice Schroeder, The Snowball: Warren Buffett and the Business of Life (2009).

35 See generally Lucian A. Bebchuk, Why Firms Adopt Antitakeover Arrangements, 152 University of Pennsylvania Law Review 713 (2003); Robert Daines \& Michael Klausner, Do IPO Charters Maximize Firm Value? Antitakeover Protection in IPOs, 17 Journal of Law, Economics, and Organization 83 (2001); Michael Klausner, Fact and Fiction in Corporate Law and Governance, 65 Stanford Law Review 1325, 1332 - 1336 (2013) (discussing the staggered board).

${ }^{36}$ Hwa-Jin Kim, The Case for Market for Corporate Control in Korea, 8 Journal of Korean Law 227, 273 (2008).

37 See Lucian Bebchuk \& Oliver Hart, A Threat to Dual-Class Shares, Financial Times, May 31, 2002. But see Ronald Masulis et al., Agency Problems at Dual-Class Companies, 64 Journal of Finance (2009) (finding evidence supporting the hypothesis that managers with greater control rights in excess of cash-flow rights are more likely to pursue private benefits at the expense of outside shareholders).

38 Article 369, Paragraph 1 of the KCC. For the rule, see generally Sanford Grossman \& Oliver Hart, One Share - One Vote and the Market for Corporate Control, 20 Journal of Financial Economics 175 (1988); Andrei Shleifer \& Robert Vishny, Large Shareholders and Corporate Control, 94 Journal of Political Economy 461 (1986); Shaun Martin \& Frank Partnoy, Encumbered Shares, 2005 University of Illinois Law Review 775. See also Bernard Black \& Reinier Kraakman, A Self-Enforcing Model of Corporate Law, 109 Harvard Law Review 1911, 1945 - 1946 (1996) (finding that the one share one vote regime has value). 
Like it or not, Samsung Group's future may determine at least the near future of the Korean economy. Together with Hyundai Motor Company Group, Samsung is the only Korean business organization that remains competitive in the ever challenging global markets. If one does not wish Samsung's failure due to its corporate governance issues, and given that Samsung itself cannot solve the problems they have satisfactorily, legislative measures will become inevitable to the extent that they do not violate the constitution and fundamental principle of economic justice. Introduction of the dual-class commons into the KCC may well contribute to the solution under the condition that Samsung follows suit of Wallenberg in terms of corporate citizenship.

To be sure, it is beyond the scope of this Essay to figure out how Samsung may use the dual-class commons in its restructuring, if introduced. It may use methods such as conventional coercive exchange offers ${ }^{39}$ and adding new classes. ${ }^{40}$ Numerous factors shall be taken into account in such a restructuring and unforeseen barriers may also come up with any plan. However, it is certain that Samsung may enjoy more flexibility benefiting the new legal environment. Perhaps, the holding structure - as discussed below - with a dualclass regime comparable to Investor in the Wallenberg Sphere may provide Samsung with a good example.

\section{INDUSTRY AND FINANCE}

The Wallenberg Sphere structured the group into two segments, i.e., financial group and non-financial operational group. The two groups are controlled by Investor, but managed independently. On the finance side, now almost 160 year old bank Enskilda Banken (SEB) is in charge. The Wallenberg established Investor for SEB's holdings some one hundred years ago, when the law restricted bank ownership of shares in industrial firms.

\section{A. The Issue}

As mentioned above, the typical Korean conglomerate structure, including that of Samsung, is characterized by cross as well as circular shareholdings amongst affiliated companies. Many of them are private companies about which not much information is available to the outside. These firms conduct

39 See, e.g., Richard S. Ruback, Coercive Dual-Class Exchange Offers, 20 Journal of Financial Economics 153 (1988).

40 See, e.g., Steven M. Davidoff, New Share Class Gives Google Founders Tighter Control, DealBook, April 13, 2012. 
significant volumes of related party transactions. ${ }^{41}$ However, what if the related party transactions were to take place involving financial institutions?

Ownership in Korean commercial banks is highly dispersed. Major banks are owned by foreign investors with no controlling interest. Under the Banking Act, there is a ten percent basic ceiling on bank ownership by a single shareholder. ${ }^{42}$ It is understood that the ceiling was introduced to effectively bar the Chaebols', in particular Samsung's, ownership in commercial banks. The only issue is that the government exercises a huge influence on the corporate governance of banks. ${ }^{43}$ On the other hand, non-banking financial institutions in Korea are members of big corporate groups, the Chaebols. The ownership in such financial institutions, securities firms, insurance companies, and savings banks, etc., is concentrated. They are under the control of controlling shareholdermanagers or affiliated firms which again are controlled by families or individuals. The trouble is that the non-banking financial institutions have other important stakeholders besides managers, employees and shareholders, i.e., customers and taxpayers. The deposit insurance program also applies to the institutions. Moral hazard and conflict of interests as exemplified by recent scandals ${ }^{44}$ should be addressed through proper corporate governance arrangements and financial regulations.

The Korean government and law makers have been struggling with the issue of 'separation of industry and finance.' The core of the discussion is if the

41 See generally Gerard Hertig \& Hideki Kanda, Related Party Transactions, in: The Anatomy of Corporate Law 101 (2004).

42 Article 15, Paragraph 1 of the Banking Act.

${ }^{43}$ Hwa-Jin Kim, Taking International Soft Law Seriously: Its Implications for Global Convergence in Corporate Governance, 1 Journal of Korean Law 1 (2001); Hwa-Jin Kim, Living with the IMF: A New Approach to Corporate Governance and Regulation of Financial Institutions in Korea, 17 Berkeley Journal of International Law 61 (1999).

44 The savings banks scandal in 2011 was a reincarnation of the savings and loans scandals in the United States in 1990s. The controlling shareholder-managers of the troubled savings banks simply stole money from their banks due to the lack of stringent supervision. Briberies were also involved in some cases. Reform efforts have largely been unsuccessful due to lobbies to the lawmakers. But, most savings banks were not members of big corporate groups. Recent scandals involve member firms of big corporate groups. One such example is Tongyang Group, which failed in 2013. It turned out that Tongyang Securities sold corporate bonds issued by ailing affiliates to its customers assuring that the issuers were sound. Many customers were attracted by an unusually high interest rate, so they were aware of the potential risks, but apparently took the risk believing in 'too big to fail.' See Tongyang Investigation Widens, Korea JoongAng Daily, Oct. 8 , 2013. Hyosung Group currently is under criminal investigation, but it appears that they used the group's member capital company like a controlling shareholder family's private cash register. See Prosecution Has Something to Prove, Korea JoongAng Daily, Oct. 15, 2013. 
law should ban industrial firms' control over financial firms, i.e., whether Korea should ban or restrict ownership in non-banking financial institutions by operational companies in corporate groups which are controlled by families. The concern here is that industrial firms may abuse financial firms, and their investors and customers, for the benefit of their shareholders, including the controlling shareholder and his or her family members. Again, Samsung is in the middle of the controversy because Samsung Group comprises of financial and non-financial operational firms under the ultimate control of a family.

\section{B. Pros and Cons}

Opinions favoring the separation are based on mistrust in the financial supervisory system. As a matter of fact, the savings bank scandal and the recent failure of some non-banking financial institutions support the validity of the claim for separation. Ex post regulation cannot be trusted. But, the core of the proseparation arguments is the conflicts of interest. Families in control of the group and/or operational member firms of the group may harm the financial firm through tunneling and/or unfairly favoring member firms within the group, its customers and eventually taxpayers along with systemic risk. Also, a separation may facilitate fair competition between corporate groups with and without financial firms.

Opinions against the separation, on the other hand, emphasize that no country regulates ex ante the new entry into the non-banking industry. Prudential rules and tight financial supervision will ensure the soundness of the financial institution. And, as far as economic rational is concerned, a similar argument favoring the reinstatement of the Glass-Steagall Act of 1933 applies here, i.e., separation blocks the creation of economies of scale and scope and prevents conglomerates from enjoying the financial synergy with stable cash flow. As a result it may have adverse impact on the international competitiveness of the local financial institutions and consumer benefits. ${ }^{45}$ The argument also points out that the Korean banks ended up being owned by foreign investors due to the ban on ownership of Chaebols in commercial banks. The same thing can happen to the non-banking financial institutions if more structural regulation is added. Regarding the possibility that operational firms may abuse financial firms, they

${ }^{45}$ For the discussion, see Hwa-Jin Kim, A Global Structural Regulation of Financial Institutions?, 52-4 Seoul Law Journal 169, 180 - 185 (2011); Charles K. Whitehead, The Volcker Rule and Evolving Financial Markets, 1 Harvard Business Law Review 39 (2011); Eugene A. Ludwig, Assessment of Dodd-Frank Financial Regulatory Reform: Strengths, Challenges and Opportunities for a Stronger Regulatory System, 29 Yale Journal on Regulation 181, 194 (2012); Jonathan R. Macey \& James P. Holdcroft, Jr., Failure is an Option: An Ersatz-Antitrust Approach to Financial Regulation, 120 Yale Law Journal 1368, 1409-1410 (2011). 
emphasize that the reality usually works the other way around. Operational firms within a group support financial firms through providing business opportunities arising from the operational firms. ${ }^{46}$

The Korean legislature is currently discussing the periodic review on controlling shareholders' personal records. If proven that the controlling shareholder or his/her relatives did commit crime or wrongdoing, the controlling shareholder shall lose control over the firm through voting right restriction or administrative order to dispose of the shares in the firm in the stock market. Besides the question of whether such a drastic measure would survive the constitutional law challenge, the financial services industry strongly opposes the legislative move arguing that the corporate governance of non-financial institutions can be determined by factors that lie beyond the scope of practical control of controlling shareholders. If adopted, the new rule can in fact be easily abused by competitors and even unfriendly or hostile family members or relatives. Furthermore, in a situation where the controlling shareholder is another company, the corporate governance of certain financial institutions will end up being changed by acts of another company's employees.

\section{Holding Structure Solution}

The compromising idea in discussion is lifting the ban on general holding company's ownership in financial institutions. Under the current Anti-monopoly and Fair Trade Act, a general holding company may not control financial firms while financial holding companies are allowed to do it. ${ }^{47}$ As an operating subsidiary cannot control financial subsidiaries in a holding structure the separation of industry and finance can practically be achieved. In this scenario the whole Samsung Group transforms itself into a holding structure following the example of LG Group and SK Group, among others, and can keep Samsung Life and other nine financial entities within the group.

46 This is actually perceived to be the bigger problem in Korea. Financial member firms rely too heavily upon businesses supplied by non-financial firms so that their identity and competitiveness as financial institutions can be compromised. It also has negative impacts on those firms' relationship with general consumers. The Korean government has recently issued guiding rules for related-party transactions involving financial institutions.

47 The law did ban the establishment of a holding company whose primary purpose was to control the management of a domestic company through equity ownership. The policy was dropped in 1999 to help big corporate groups ease the restructuring and improvement of corporate governance. For the regulation of financial holding companies (in the U.S.), see Howell E. Jackson, The Expanding Obligations of Financial Holding Companies, 107 Harvard Law Review 507 (1994). 
Another idea is the mezzanine (financial) holding company. According to this, general holding companies shall be allowed to control mezzanine holding companies that may own financial institutions. Mezzanine holding companies will become subject to strengthened financial supervision. This scenario offers a less expensive way for Samsung to deal with the issue because it does not require the restructuring of the entire group. In any case, the dual-class commons regime as in the Investor and SEB relationship in the Wallenberg Sphere would be the practical solution especially because it is likely that the Korean government would allow the dual-class regime only to private companies, if at all. ${ }^{48}$

\section{The Perils of Over-Regulation}

It is a very common phenomenon throughout history that politicians and government officials supported by scholars and other experts try to change or reform the existing system whenever a scandal takes place. Sometimes it comes with significant regulatory costs. One of the most recent examples is arguably the U.S. Sarbanes-Oxley Act of 2002, ${ }^{49}$ and the Dodd-Frank Act of 2010 may become another example. ${ }^{50}$ On the one hand, it is a constructive approach. Things must be fixed if they are broken. On the other hand, they easily forget that scandals always involve illegal and criminal acts of those people who are responsible for damages to investors, shareholders, and the economy. It is true that Korean firms may take advantage of the financial affilates in bad times. However, policy should not be formulated on a worst case and/or isolated scenario. It is like unfairly punishing honest firms for acts committed by the bad guys. It may also invite opportunistic behavior and corruptive practices in bureaucracy out of the labyrinth of regulatory and supervisory details that ultimately create further reform needs.

It has been discussed in the parliament that Samsung Life's voting rights in Samsung Electronics should be restricted through amending the Anti-monopoly and Fair Trade Act. How the idea survives the constitutional law challenge is not 36 at 274 .

${ }^{48}$ See the draft article by the Korean Ministry of Justice’s expert group in Kim, supra note

${ }^{49}$ For critical assessments, see Roberta Romano, Does the Sarbanes-Oxley Act Have a Future?, 26 Yale Journal on Regulation 229 (2009); Roberta Romano, The Sarbanes-Oxley Act and the Making of Quack Corporate Governance, 114 Yale Law Journal 1521 (2005); William J. Carney, The Costs of Being Public After Sarbanes-Oxley: The Irony of "Going Private,"55 Emory Law Journal 141 (2006). But, see Donald C. Langevoort, The Social Construction of SarbanesOxley, 105 Michigan Law Review 1817 (2007).

50 See, e.g., Diane Katz, Dodd-Frank at Year Three: Onerous and Costly, Heritage Issue Brief No. 3993, July 19, 2013; Paul Rose \& Christopher J. Walker, Dodd-Frank Regulators, CostBenefit Analysis, and Agency Capture, 66 Stanford Law Review Online (2013). 
an issue for politicians. The Constitutional Court of Korea has become the most active constitutional law court in the world reviewing and overturning unconstitutional laws passed by the Korean parliament. When Samsung Life in fact gets separated from the Samsung Group structure, the family control over the group may become weak. There is no way for the family to maintain effective control over Samsung Electronics, the world's thirteenth largest firm, without the 'assistance' of Samsung Life. This puts Samsung in the awkward position that it seems to oppose or resist the government policy. As a result, the whole discussion on the separation of industry and finance has somehow become a Samsung issue which is misleading and unfortunate. The lawmakers seem to try to avoid such an impression, but it is obvious simply because the Samsung issue stands out in any discussion.

\section{CONCLUDING REMARKS}

As Gilson observed, "the presence of family ownership.. facilitates the development and maintenance of the reputation necessary for a corporation's commercial success" in a bad commercial law environment. ${ }^{51}$ The best example is the Wallenberg Sphere in Sweden, a Scandinavian legal system jurisdiction. ${ }^{52}$ The family business has successfully survived five generations. The same history of success may repeat in Korea. The first step would be to remove widespread biases against family-controlled corporate groups with concentrated ownership by accepting the proposition that they may be efficient as well.

This Essay examined the controversial corporate governance issues of Samsung Group in comparison with those of the Wallenberg Sphere. The core difference between the structure and problems arising therefrom is the use of the dual-class commons in Wallenberg. Korean law does not allow the dual-class commons, so Samsung relies heavily upon circular shareholding through affiliated firms. This Essay concludes that the introduction of the dual-class commons in the KCC would ease the pain in difficult corporate governance problems Samsung and other Korean firms face should the Wallenberg model be a legitimate one for the Korean economy and society. This Essay also emphasizes that such a change

51 See Ronald J. Gilson, Controlling Family Shareholders in Developing Countries: Anchoring Relational Exchange, 60 Stanford Law Review 633, 636 (2007).

${ }^{52}$ For discussions on the family-controlled U.S. firms, see Danny Miller et al., Are Family Firms Really Superior Performers?, 13 Journal of Corporate Finance 829 (2007) (“Although international evidence suggests that families may be unhelpful to firm performance, recent analyses of U.S. public companies indicate that family firms outperform.”) See also, Belen Villalonga \& Raphael Amit, How do Family Ownership, Control and Management Affect Firm Value?, 80 Journal of Financial Economics 385 (2006). 
may be legitimate if and only if Korean firms commit socially responsible corporate citizenship.

Finally, the policy issue in Korea now is whether stronger regulation on governance of corporate groups with non-banking financial institutions is in order. Samsung is in the middle of the controversy. Special legislative initiatives have also been taken to address the issue. This Essay briefly explained and analyzed the recent developments in corporate governance of non-banking financial institutions in Korea and suggested that further regulation would not be efficient and rather produce bureaucracy and corruptive practices. If Samsung did not caused the controversy, it is fair to say Samsung may be counted as collateral damage. 